\title{
Environmental Suitability of the City of East Sarajevo for the Location of Municipal Solid Waste Disposal Site Using a GIS Based Multi-Criteria Analysis
}

\author{
Sanda Šušnjar ${ }^{1 *}$, Jelena Golijanin ${ }^{1}$, Milica Pecelj ${ }^{1,2}$, Mariana Lukić Tanović¹, \\ Aleksandar Valjarević ${ }^{3}$ \\ ${ }^{1}$ University of East Sarajevo, Faculty of Philosophy, Department of Geography, \\ Alekse Šantića 1, 71420 Pale, Bosnia and Herzegovina \\ ${ }^{2}$ Geographical Institute 'Jovan Cvijić' Serbian Academy of Science and Arts, \\ Djure Jakšića 9, Belgrade, 11000, Serbia \\ ${ }^{3}$ University of Belgrade, Faculty of Geography, Department of Geospatial and Environmental Sciences, \\ Studentski trg 3/III, 11000 Belgrade, Serbia
}

Received: 2 April 2021

Accepted: 25 June 2021

\begin{abstract}
World production growth affected a rise in the amount of waste generated. In these circumstances proper waste management becomes a highly important issue. The protection of the environment from degradation requires a multi-dimensional approach to this problem. Integration of multicriteria decision making with the geographic information systems provides a useful methodology and a helpful instrument in waste management, particularly in the assessment of environmental suitability for the location of municipal solid waste disposal sites. Multidimensional approach is realized through analytic hierarchy process (AHP) in the determination of sub-criteria and criteria values and final site selection. Geographic information systems (GIS) provide spatial data input and give an insight into final result of the decision-making process. Integrated methodology is applied in suitability analysis of the City of East Sarajevo for the location of municipal solid waste disposal site (MSWDS). Ten criteria were evaluated through pair-wise comparison matrices and suitability map was obtained using weighted linear combination algorithm in GIS. Extracting high suitability area, the largest locations were evaluated through AHP according to ten criteria and final site selection was made. The results indicate high applicability of integrated multi-criteria analysis and GIS
\end{abstract}

*e-mail: sanda.susnjar@ff.ues.rs.ba 
methodologies for coordination of decision-making process in spatially oriented issues of environmental management.

Keywords: multi-criteria analysis, GIS, municipal waste management, environmental suitability, site selection

\section{Introduction}

Hyper production of various types of waste, including harmful and toxic waste materials, has lasting consequences in the geosystem, disrupting its balance and ability to self-regulate. Geosystem imbalance is manifested through various aspects, from climate change and ocean acidification to endangered biodiversity. In 2016, worldwide waste generated per person per day was ranging between 0.1 in Sub-Saharan Africa to $4.54 \mathrm{~kg}$ per person per day in Northern American region. Average daily waste generation in 2016 in Bosnia and Herzegovina was $0.98 \mathrm{~kg} / \mathrm{capita} /$ day which is $32 \%$ more than world average [1]. Municipal solid waste consists of food waste, plastics, cardboard, PET, glass, ash, wood, textile and other materials. The most common solid waste management strategies include several procedures, such as generation, collection, transfer and transport, processing and disposal of solid wastes [2]. Deposition of municipal solid waste at open disposal sites is the most common waste management strategy in low- and middle-income countries. Major problem for these countries is improper solid waste deposition, usually in unsanitary landfills, open dump sites and frequently used open incineration for reducing high amounts of waste. Limited land resources need to be protected from further degradation caused by gas emissions and leachate from landfills [3]. In these circumstances, the importance of sustainable waste management becomes one of the top priorities.

Proper municipal solid waste treatment can turn wastes into the potential for renewable energy production $[4,5]$. Common technologies for energy production from waste are (I) thermal conversion methods (incineration, pyrolysis, gasification), (II) biochemical conversion (anaerobic digestion, composting) and (III) landfilling with gas recovery. Thermal conversion methods refer to thermal treatment of organic matter from municipal solid waste to produce heat, fuel oil or gas [6]. Biochemical conversion includes chemical decomposition and biological digestion. These processes are based on microbic digestion and fermentation of organic biodegradable matter which turns biomass into ethanol and methane [7]. Composting is used as a natural process of recycling of organic matter which provides nutrients for soils and crops. Some of the major disadvantages of the above methods are the production of air pollutants such as $\mathrm{SO}_{2}, \mathrm{NO}_{2}, \mathrm{CO}_{2}$, $\mathrm{CH}_{4}$ and other $[6,8]$ On the other hand, landfilling is a technique of solid waste disposal which tends to reduce negative impacts on the environment by controlling and reducing greenhouse gasses emission and minimizing leachate mitigation into subsurface environment. Sanitary landfills implement engineering facilities to reduce land degradation and polluting gasses emission while pursuing to confine and compress solid wastes to the smaller area and to the lowest licit volume [912]. The creation of sanitary landfills is considered to be a reasonable solution for most developing countries as it fulfills two main solid waste management goals, protection of human health and protection of the environment while taking into account affordable financial resources [13-15].

There is high research interest in the issues of waste management and many studies are dealing with the human - environment interrelations [16-19] particularly the environmental suitability for the purpose of locating municipal solid waste disposal sites [20-26]. The present research deals with suitability analysis for locating the MSWDS in The City of East Sarajevo in Bosnia and Herzegovina. The analysis consists of two major parts. The first part represents the analysis of environmental suitability, while the second part of the analysis provides a comparison of the identified solid waste disposal sites and final sites ranking according to the given criteria. Analysis based on multicriteria optimization methods are particularly important for dealing with such a complex problem as solid waste management. Integration of multi-criteria decision making with GIS is a valuable tool when dealing with spatially oriented waste management issues which require a dynamic and comprehensive approach [27].

The aim of this work is to select and analyze main factors determining environmental suitability for location of Municipal solid waste disposal site (MSWD) and the final site selection in The City of East Sarajevo. This work gives an insight into the availability and opportunities of integrated multi-criteria analysis and geographic information systems in waste management and planning, specifically for selecting the most suitable location of MSWDS.

\section{Material and Methods}

\section{Case Area}

The city of East Sarajevo extends from $18^{\circ} 20^{\prime} 7^{\prime \prime} \mathrm{E}$ to $19^{\circ} 1^{\prime} 30^{\prime \prime} \mathrm{E}$ and from $44^{\circ} 7^{\circ} 25^{\prime \prime} \mathrm{N}$ to $43^{\circ} 35^{\circ} 15^{\prime \prime} \mathrm{N}$, covering the area of $1447.58 \mathrm{~km}^{2}$ or $2.82 \%$ of the entire Bosnia and Herzegovina territory. From geomorphological perspective, the City of East Sarajevo is located in eastern, mountainous part of Bosnia and 
Herzegovina, spreading over the South and Southeast parts of the Sarajevo Valley and is surrounded by Dinaric Alps mountain range. The city expands between altitudes of $510 \mathrm{~m}$ and $1916 \mathrm{~m}$. Only 8\% of the territory is located at the altitude below $800 \mathrm{~m}$, while almost $70 \%$ of the territory is situated between 800 and $1200 \mathrm{~m}$. Around $6 \%$ of the territory is located in altitudes above $1400 \mathrm{~m}$. Even though the city is less than $110 \mathrm{~km}$ by air distance from the Adriatic Sea, its climate is highly influenced by continental circulation from the north, due to relief configuration and higher altitudes. Lower parts of the city have temperate climate which gradually changes by the altitude into continental and mountainous climate. Average annual temperature in lower part of the city is $10.3^{\circ} \mathrm{C}$ with annual sum of rainfalls of $990 \mathrm{~mm}$, while in higher parts, the average annual temperature is $8.2^{\circ} \mathrm{C}$ with annual rainfalls of $1230 \mathrm{~mm}$

The City of East Sarajevo is a part of the Republic of Srpska entity in Bosnia and Herzegovina and its current name and territorial extent dates from 2006. It covers the administrative territories of 6 municipalities: Sokolac, Pale, Istocno Novo Sarajevo, Istocna Ilidza, Istocni Stari Grad and Trnovo RS. The city borders with 13 surrounding municipalities. According to the census report from 2013, the population of the city was 59916 people [28]. The largest municipalities are Sokolac and Pale which take $82 \%$ of the City of East Sarajevo with $53 \%$ of the city population. There are 215 settlements. Almost 65\% of the population live in 5 urban settlements, on the $2.4 \%$ of the area (Fig. 1). The most densely populated municipalities are the ones in the lower part of the city, the municipality of Istocna Ilidza with population density of 493 people per $\mathrm{km}^{2}$, and the municipality of Istocno Novo Sarajevo, with 274 people per $\mathrm{km}^{2}$. Densely populated areas in the city and insufficiently developed waste management infrastructure highly influence spatial exposure to the illegal dumping, while raising the possibility of potential harmful effects on human health and environmental degradation. Currently, at the lower part of the city, there is one collective unsanitary landfill 'Krupacke stijene', located in the municipality of Trnovo RS. This landfill is used for solid waste disposal by the municipalities of Istocno Novo Sarajevo, Istocna Ilidza and Trnovo RS. In the upper mountainous part of the city, in the municipality of Pale, solid waste has been disposed to local landfill 'Stanisica dolovi', while in the municipality of Sokolac there is not any landfill. According to intermunicipal agreement, waste from this municipality is transported to local landfill in the neighbouring municipality of Rogatica. Due to ineffective waste management particularly insufficiently developed

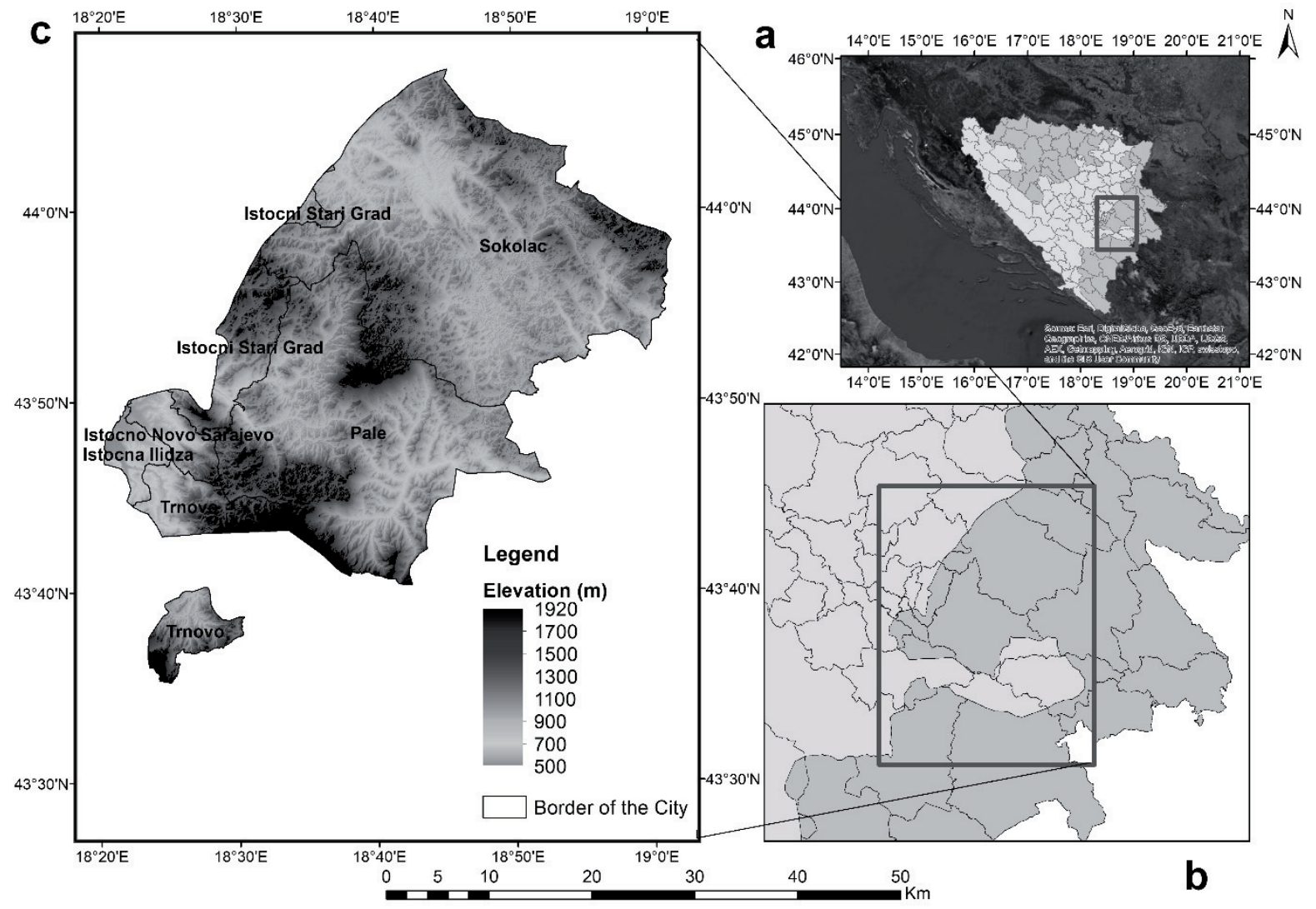

Fig. 1. Location of study area a) Territory of Bosnia and Herzegovina; b) Territory of the city of East Sarajevo; c) Relief map of the East Sarajevo city. 
network of organized waste collection system, nonimplementation of waste separation and selection, poor waste recycling and lack of sanitary landfills, all municipalities of the city struggle with illegal dumping, threatening its environment, especially their rural surroundings [29-32]. Bearing in mind the very specific territorial and spatial distribution of the city of East Sarajevo, the population is mostly concentrated in few urban settlements of the city, causing numerous environmental problems. Most of the rural settlements are not included in local municipal solid waste collection system. These disadvantages increase possibilities of improper waste disposal and illegal dumping which further intensifies the need to resolve the most urgent problem of locating sanitary landfill for municipal solid waste within the territory of the city.

\section{Data Description}

Suitability analysis for the location of MSWDS in the City of East Sarajevo is performed according to ten criteria: elevation, slope, land cover, distance from main roads, distance from local roads, distance from springs, distance from watercourses, distance from urban settlements, distance from rural settlements and hydrogeological features of rocks. The Criteria used for the purpose of this analysis are derived on the basis of previous works dealing with spatial suitability analysis for the location of municipal solid waste disposal site. Elevation data and slope data are obtained using digital terrain model Aster Global DEM [33]. Watercourses and locations of springs are gained in digitizing topographic maps in scale of 1:100000 [34]. Urban and rural settlements data, main roads and local roads data are derived from base map Google Hybrid [35] in QGIS software package [36]. Data for Hydrogeological features of rocks are obtained by digitalization of hydrogeological map of Bosnia and Herzegovina in scale 1:500000 [37]. Land cover data is obtained through LANDSAT 8 satellite imagery processing [38] by reclassifying pixels into four dominant land classes, applying maximum likelihood classification method [39].

\section{Methodology}

Waste management problems often require consideration of different influencing factors such as environmental, economic and social, but are also highly determined by stakeholder's capability for comprehensive perception and problem structuring in the decision-making process. As this paper aims to evaluate environmental suitability for the purpose of locating municipal solid waste disposal site and to rank identified locations by its suitability, it is necessary to integrate hierarchical problem structuring in order to find the best solution for this task. Geographic information system is considered to be decision support system due to its capability to efficiently integrate geospatial information with multiple socio-economic data while enabling information cross-combination and synthetic modelling. In addition, multi-criteria decision support analysis (MCDA) provides multiple techniques and procedures for hierarchical problem structuring, but also designing, evaluating and prioritizing the decisionmaking problems [40]. For these reasons, we used combined methodological approach which integrates spatial modelling based on geographical information systems and remote sensing data with overlay mapping and multi-criteria decision making (MCDM) through pairwise comparison matrices in analytic hierarchy process (AHP). Boolean restriction model was applied in order to completely exclude unsuitable or sensitive area from further analysis.

In the first part of the analysis, the problems of improper waste disposal and inadequacy of municipality waste disposal sites in the City of East Sarajevo were identified. The second step involved search of spatial planning documentation, analysis of the city's development strategies. Also, previously published scientific papers were analyzed for the identification of major criteria influencing the problem of municipal solid waste disposal site location. Identification and selection of highly influencing criteria is a very important issue in the process of problem structuring and it is based mostly on expert knowledge of scientists and professionals within the filed. For the purpose of this work, the criteria were selected based on a review of previously published scientific papers and frequency of criteria occurrence within this type of analysis.

The second part of the analysis involved data preparation and integration into GIS. This step included map digitalization, projection transformation and vectorization procedure. It also included data integration from multiple resources such as census report data, local environmental action plans, cartographic documentation and digital elevation models. In this part of the analysis, remote sensing techniques were used for the extraction of recent land cover data as highly important criteria in environmental suitability analysis for municipality solid waste disposal site (MSWDS).

\section{Remote Sensing Data}

Remote sensing and satellite imagery play a significant role in providing data of the current environmental and socioeconomic condition of the territory based on land cover and land use data. Satellite imagery reclassification is performed through several steps which include selection of suitable classification technique, selection of training samples, image preprocessing, feature extraction, post classification processing and accuracy assessment [41]. Commonly used classification algorithms contain K-means, minimum distance, ISODATA, maximum likelihood, minimum distance to mean.

For satellite imagery with coarser resolution than the extent of the land cover pattern it is better 
to use super-resolution or super-pixel mapping. For the approximation of probability at finer sub-pixel level, indicator cokriging can be used to calculate the probability that the pixel (subpixel) at fine spatial resolution belongs to a particular class in relation to coarse resolution fractions and limited set of class labels defined for already acquainted pixels (samples) [42-44]. These methods significantly improve landcover classification as they provide spectral unmixing and determination of spectral signatures of those pixels which have composite spectral signature from different categories. For the purpose of this analysis, $30 \mathrm{~m}$ spatial resolution data of LANDSAT 8 imagery was used to produce land cover data. Supervised maximum likelihood classification method was used, based on the assumption of normality distribution in training samples. Through the applied algorithm, probability density function was calculated for each land cover category. Pixels were assigned in membership according to maximum likelihood (probability) of certain pixel occurring in probability density function of each category $[45,46]$. The four landcover classes were extracted and applied in further analysis.

For the third part of the analysis, there are many models which could be applied for the analysis of environmental suitability for the municipal solid waste disposal site and final site selection. Three major groups of approaches are a) map overlay techniques b) multi-criteria evaluation and c) soft computing or geocomputing techniques (artificial intelligence) [47]. Nowadays, combined methodological approach is more preferred in dealing with complex spatial problems such as environmental suitability analysis and solid waste disposal site selection. Combined methods of GIS and AHP is used for landfill site selection in Lahore, Pakistan [48]. Combined GIS and Fuzzy AHP is applied in suitability analysis for landfill site selection in Kolkata, India [49], for solid waste disposal site location in Iranshahr County in Iran [50]. Also highly applied are combined methods of GIS, AHP or Fuzzy AHP and remote sensing techniques [51, 52] and combined GIS, AHP and TOPSIS for landfill site selection [53, 54]. For the study, geographic information systems, remote sensing and multi-criteria decision making methods were integrated due to high necessity for efficient integration of geospatial information considering multiple and diverse resources, while taking into account the possibilities of MCDM for hierarchical structuring of such a complex environmental problem with many different factors and stakeholders involved in the decision-making process.

\section{Multi-Criteria Decision Making (MCDM) - Analytic Hierarchy Process}

This method is an effective tool in making complex decisions, helping the decision maker to prioritize and make the best decision. The AHP is based on the principle of reducing and decomposing a complex decision into a series of comparative matrices, followed by a synthesis of the results. This method also contains a useful technique for checking the consistency of the decision maker, reducing the bias in the decisionmaking process [55]. Analytic hierarchy process as decision making includes a set of assessment criteria and a set of alternative solutions/options among which the best decision should be made. The AHP method goes through several steps.

The first step is defining a problem to be solved and structuring the problem into hierarchy of interrelated decision elements where the first level is an overall goal, while the medium level represents criteria upon which subsequent elements depend. The bottom level represents the alternatives or choice selection. The second step represents the construction of pairwise comparison matrices where each element (criterion) is used for element comparison in the level below. In order to make a comparison of the criteria $(j)$ and define its importance relative to each other, it is necessary to create real matrix $m^{*} m$ where $m$ represents number of criteria $j$ used for valuation ( $m=1$ to 10). Comparison matrix is formed of paired reciprocal values. Relative importance of the criteria is measured in scale from 1 to 9, according to Saaty's fundamental scale of relative numbers (Table 1). After creating comparison matrices and normalized pairwise comparison matrices, it is possible to calculate weight value $w$ for all of the criteria.

The third step represents synthesis of the priorities (alternatives). This is performed by making comparison matrices $\mathrm{B}^{(\mathrm{j})}$ of $n^{*} n$ alternatives, comparing all the alternatives by each criterion ( $n=1$ to 10$)$ and applying method of principal Eigen vector [56]. In the process of creating pairwise comparison matrices, it is necessary to check the consistency of judgments made by decision makers. Consistency of judgments in comparison matrices is checked using consistency index (CI) and can be calculated as:

$$
\mathrm{CI}=\left(\lambda_{\max }-\mathrm{n}\right) /(\mathrm{n}-1)
$$

...where $\lambda_{\max }$ is the largest and principal value of the matrix and it can be calculated from the matrix itself and $n$ represents number of criteria. The perfect consistency of judgments made would have a value of $\mathrm{CI}=0$, but a small degree of inconsistency in decision making is tolerated. The value of CI is compared with the value of the random index (RI) through consistency ratio or CR $[57,58]$. The RI (Table 2) is the assigned judgment value that would be obtained if the judgment values were totally random and it depends upon number of items in comparison matrices. If the CR is equal to $10 \%$ or less, then the judgments and estimates are accepted. Then:

$$
\mathrm{CR}=\mathrm{CI} / \mathrm{RI}
$$

The fourth part of the analysis includes checking the consistency of judgments in the assessment of criteria 
Table 1. Fundamental scale of relative numbers [56].

\begin{tabular}{|c|c|c|}
\hline $\begin{array}{l}\text { Intensity if an } \\
\text { importance }\end{array}$ & Definition & Explanation \\
\hline 1 & Equal importance & Two activities contribute equally to the objective \\
\hline 3 & $\begin{array}{l}\text { Moderate importance of one over } \\
\text { the other }\end{array}$ & $\begin{array}{l}\text { Experience and judgment moderately favor one activity } \\
\text { over the another }\end{array}$ \\
\hline 5 & Essential and strong importance & Experience and judgment strongly favor one activity over another \\
\hline 7 & Very strong importance & An activity is strongly favored and its dominance demonstrated in practice \\
\hline 9 & Extreme importance & $\begin{array}{l}\text { The evidence favoring one activity over another is of the highest possible } \\
\text { order of affirmation }\end{array}$ \\
\hline $2,4,6,8$ & $\begin{array}{l}\text { Intermediate values between two } \\
\text { judgments }\end{array}$ & When compromise is needed \\
\hline
\end{tabular}

significance but also investigating the sensitivity of final priorities ranking to the changes in criteria weights. Verification of dependence of the synthesis score on the specific weights of the criteria is performed by sensitivity analysis.

\section{Sensitivity Analysis}

The ranking results contained in the synthesis score depend on the specific weighting coefficients (w) assigned to the individual criteria. In order to examine the sensitivity of the results to changes in the weight coefficients of the given criteria, it is necessary to calculate the synthesis score for all the extracted locations, under the condition that each of the ten criteria have the same specific weights. In order to examine how robust final judgment is (ranking of the alternatives) it is recommended to check whether the result would change if the criteria weights were different [59]. The total weight score for all criteria has value 1 . For the purpose of this work, the criteria weight values of each criterion are set to the same value of 0.100 .

The fifth part of the analysis involves the integration of the AHP method and GIS modelling through the determination of weight coefficients for each criterion and in the process of the identification of the alternatives and selection of final best ranked alternative. The method of weighted linear combination (WLC) is applied for the calculation of normalized weight values and for final priority selection.

\section{Weighted Linear Combination}

This method is based on the concept of weighted average in which continuous criteria are standardized into common numerical range and then combined using a weighted average. Data values for each criterion are stored within map layers in GIS. In this study, the concept of weighted average is applied where all criteria are standardized to same numeric range and combined by means of a weighted average. In this process, the decision maker determines the relative importance of each criterion by the assigning the weight value to each criterion (raster layer). A total score for each alternative is obtained by multiplying the weight value of the criterion by the scaled value given to the alternative on that criterion, and summing the products over all criteria. The results are calculated for all of the alternatives and the one with the highest overall score is finally chosen. In this method, the criteria are combined by means of weighting coefficients, after which the results are summarized to obtain a suitability map [6062]. Decision role in WLC can be explained by:

$$
S=\sum w_{i} x_{i}
$$

...where $S$ represents suitability, $w$ is weight of factor $i, x$ is criterion score of factor $i$.

The sixth, final part of the analysis, represents extraction of restricted area in relation to influencing criteria. In this procedure rasters of constrains are created using Boolean constrains method and combined with suitability raster. Final suitability is presented in four classes: restricted area, low suitability, moderate suitability and high suitability area.

\section{Boolean Constrains}

The obtained raster of environmental suitability does not exclude the area which is unsuitable for the location of municipal solid waste disposal site by any of these criteria. In order to protect the area unsuitable for the location of the MSWDS, rasters of restrictions were created to mask the area where

Table 2. Values of Random index (RI) for small problems [57, 58].

\begin{tabular}{|c|c|c|c|c|c|c|c|c|c|c|}
\hline $\mathrm{m}$ & & 2 & 3 & 4 & 5 & 6 & 7 & 8 & 9 & 10 \\
\hline $\mathrm{RI}$ & & 0 & 0.58 & 0.90 & 1.12 & 1.24 & 1.32 & 1.41 & 1.45 & 1.49 \\
\hline
\end{tabular}


Table 3. Restricted area.

\begin{tabular}{|c|c|}
\hline Criteria & Restricted (0) \\
\hline Distance from springs & $\mathrm{d} \leq 500 \mathrm{~m}$ \\
\hline Distance from watercourses & $\mathrm{d} \leq 500 \mathrm{~m}$ \\
\hline Distance from main roads & $\mathrm{d} \leq 100 \mathrm{~m}$ \\
\hline Distnace from urban settlements & $\mathrm{d} \leq 500 \mathrm{~m}$ \\
\hline Land cover & $\begin{array}{c}\text { Agricultural land } \\
\text { / artificial surface }\end{array}$ \\
\hline Elevation & $\mathrm{h} \geq 1400 \mathrm{~m}$ \\
\hline
\end{tabular}

the location of the MSWDS is not allowed. The model of Boolean constraints is applied to isolate areas which are completely unsuitable for consideration. Restriction rasters were obtained by reclassifying the criteria rasters to a value of 0 (unsuitable) and a value of 1 (suitable). The following criteria were used to determine the restricted area: distance from springs, distance from watercourses, land cover, distance from main roads, distance from urban centres and elevation (Table 3). Raster of restrictions (unsuitable area) is combined with the previously obtained suitability score raster. This procedure is performed according to:

$$
S=\Sigma w_{i}^{*} x_{i}^{*} \Pi C_{j}
$$

$S$ represents final suitability score, $w_{i}$ is weight value of a criteria $i$ (factor $i$ ) and $x_{i}$ is a criterion score of a factor $i$, $\Pi \mathrm{C}_{j}$ is criterion score of the constraint $j$ [63].

\section{Results and Discussion}

\section{Calculation of Sub-Criteria and Criteria Influence in AHP}

Relative importance of sub-criteria and relations between the criteria are gained through its corresponding weight values. Consistency rates (CR) are calculated for all pair-wised matrices created in AHP (Table 4). The results of the AHP analysis suggest that the most important criteria in defining spatial suitability for the location of MSWDS are criteria: distance from springs, distance from watercourses and hydrogeological features of rocks. Weight values of the criteria are in range 0.210 to 0.169 . In addition, criteria of the land cover and the slope have high importance for suitability assessment. Area at distance from springs further than $1500 \mathrm{~m}$ is considered highly suitable for locating solid waste disposal site, while the least suitable is distance closer than $500 \mathrm{~m}$ from springs. Also, area at distance

Table 4. Criteria weight values and sub-criteria weight values with consistency rates.

\begin{tabular}{|c|c|c|c|c|}
\hline Criteria & Criteria weight value $w$ & Sub-criteria & Sub-criteria weight value & C.R. \\
\hline \multirow{5}{*}{ Elevation (m) } & \multirow{5}{*}{0.023} & $400-800$ & 0.462 & \multirow{5}{*}{0.0267} \\
\hline & & $800-1000$ & 0.313 & \\
\hline & & $1000-1200$ & 0.129 & \\
\hline & & $1200-1400$ & 0.062 & \\
\hline & & $\mathrm{h}>1400$ & 0.033 & \\
\hline \multirow{5}{*}{ Slope $\left(^{\circ}\right)$} & \multirow{5}{*}{0.100} & $0-10$ & 0.455 & \multirow{5}{*}{0.08} \\
\hline & & $10-20$ & 0.292 & \\
\hline & & $20-30$ & 0.162 & \\
\hline & & $30-40$ & 0.056 & \\
\hline & & $\mathrm{s}>40$ & 0.035 & \\
\hline \multirow{4}{*}{ Land cover } & \multirow{4}{*}{0.109} & Agriculture area & 0.053 & \multirow{4}{*}{0.0353} \\
\hline & & Artificial surfaces & 0.082 & \\
\hline & & Forest & 0.275 & \\
\hline & & Grasslands and pastures & 0.590 & \\
\hline \multirow{4}{*}{$\begin{array}{l}\text { Hydrogeological } \\
\text { features }\end{array}$} & \multirow{4}{*}{0.169} & $\begin{array}{c}\text { Low permeable rocks } \\
\text { without aquifers }\end{array}$ & 0.501 & \multirow{4}{*}{0.0824} \\
\hline & & $\begin{array}{c}\text { Low permeable rocks with possible } \\
\text { local importance aquifers }\end{array}$ & 0.335 & \\
\hline & & Moderate permeability rocks & 0.122 & \\
\hline & & High permeability rocks & 0.042 & \\
\hline
\end{tabular}


Table 4. Continued.

\begin{tabular}{|c|c|c|c|c|}
\hline \multirow{6}{*}{$\begin{array}{l}\text { Distance from main } \\
\text { roads }(\mathrm{m})\end{array}$} & \multirow{6}{*}{0.036} & $0-100$ & 0.027 & \multirow{6}{*}{0.0381} \\
\hline & & $100-200$ & 0.377 & \\
\hline & & $200-300$ & 0.253 & \\
\hline & & $300-400$ & 0.176 & \\
\hline & & $400-500$ & 0.099 & \\
\hline & & $d>500$ & 0.068 & \\
\hline \multirow{6}{*}{$\begin{array}{l}\text { Distance from local } \\
\text { roads }(\mathrm{m})\end{array}$} & \multirow{6}{*}{0.028} & $0-50$ & 0.028 & \multirow{6}{*}{0.0353} \\
\hline & & $50-100$ & 0.376 & \\
\hline & & $100-150$ & 0.241 & \\
\hline & & $150-200$ & 0.165 & \\
\hline & & $200-250$ & 0.108 & \\
\hline & & $d>250$ & 0.083 & \\
\hline \multirow{4}{*}{$\begin{array}{l}\text { Distance from urban } \\
\text { settlements }(\mathrm{m})\end{array}$} & \multirow{4}{*}{0.079} & $0-500$ & 0.046 & \multirow{4}{*}{0.0777} \\
\hline & & $500-1000$ & 0.197 & \\
\hline & & $1000-1500$ & 0.252 & \\
\hline & & $d>1500$ & 0.505 & \\
\hline \multirow{4}{*}{$\begin{array}{l}\text { Distance from rural } \\
\text { settlements }(\mathrm{m})\end{array}$} & \multirow{4}{*}{0.068} & $0-250$ & 0.058 & \multirow{4}{*}{0.0244} \\
\hline & & $250-500$ & 0.124 & \\
\hline & & $500-750$ & 0.297 & \\
\hline & & $d>750$ & 0.521 & \\
\hline \multirow{3}{*}{$\begin{array}{c}\text { Distance from } \\
\text { watercourses (m) }\end{array}$} & \multirow{3}{*}{0.178} & $0-500$ & 0.06 & \multirow{3}{*}{0.0697} \\
\hline & & $500-1000$ & 0.29 & \\
\hline & & $d>1000$ & 0.65 & \\
\hline \multirow{4}{*}{$\begin{array}{l}\text { Distance from springs } \\
\text { (m) }\end{array}$} & \multirow{4}{*}{0.210} & $0-500$ & 0.057 & \multirow{4}{*}{0.042} \\
\hline & & $500-1000$ & 0.122 & \\
\hline & & $1000-1500$ & 0.263 & \\
\hline & & $d>1500$ & 0.558 & \\
\hline
\end{tabular}

further from $1000 \mathrm{~m}$ of watercourses is considered the most suitable, while closer area has moderate suitability or is considered unsuitable (less than $500 \mathrm{~m}$ ).

The most suitable hydrogeological zones are low permeable rocks without aquifers mostly prevailing as shales, granites and basalts, while the least suitable are sandstones and limestones as highly permeable rocks. Considering land cover criterion, the least suitable terrains for locating the MSWDS are agriculture areas and artificial surfaces (urban area). Criteria maps were created, after calculation of weights. Maps contain raster values with previously defined sub-criteria weight values. Each criterion map containing sub-criteria weight values is multiplied by its criterion weight value and overlapped in weighted linear combination procedure. This procedure results in creation of raster map containing score values for each pixel of the raster map.
The results of the suitability analysis for the location of MSWDS in the City of East Sarajevo are obtained in multiplication of raster of constraints with the suitability raster map. The suitability map is reclassified into four different categories according to suitability score values. Score value of 0 represents area of constraints, score values ranging from 2 to 4 represent low suitability area, score values between 5 and 6 represent moderate suitability while highest score values, 7 and 8 , represent high suitability area (Fig. 2a).

The area of constraints covers $825.07 \mathrm{~km}^{2}$ or $57.34 \%$ of the territory in the City of East Sarajevo. Low suitability area occupies $69.51 \mathrm{~km}^{2}$ or $4.83 \%$, while moderate suitability area covers $513.77 \mathrm{~km}^{2}$ or $35.70 \%$ of the territory. The most suitable area covers only $2.13 \%$ or $30.67 \mathrm{~km}^{2}$ of the city. Considering suitability area by each of the six municipalities in the city (Table 5), the largest area in high suitability category is 

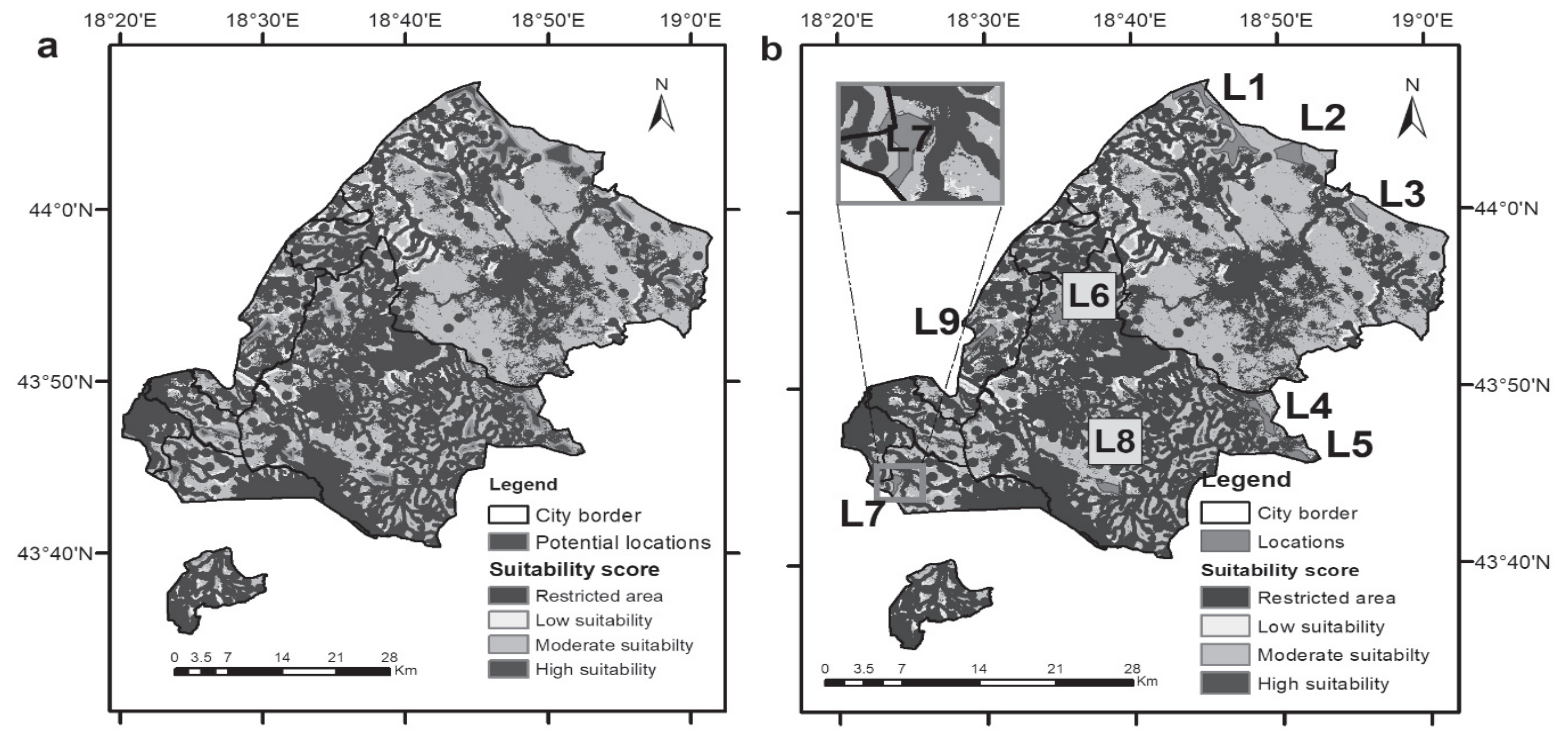

Fig. 2. Suitability map of a) the City of East Sarajevo and b) Analysed locations.

in the municipality of Sokolac as it covers approximately $3 \%$ of its territory, while the smallest area of high suitability is in the municipality of Trnovo RS, where only $1.23 \%$ of area is in high suitability category. Municipality of Istocna Ilidza is the least suitable for the location of MSWDS due to restricted area which covers more than $80 \%$ of the territory. The largest moderate suitability, almost $50 \%$ of the territory and also the smallest restricted area, $44.2 \%$ of the territory, has the municipality of Sokolac. The smallest area in moderate suitability category has municipality of Istocna Ilidza. Municipalities with the smallest percentage of the restricted area and the largest area of high suitability are Sokolac municipality and municipality of Istocno Novo Sarajevo.

Taking into account only the most suitable area of approximately $2 \%$ of the city of East Sarajevo, the 34 potential sites were identified and only sites covering an area larger than $1 \mathrm{~km}^{2}$ were analyzed. Only 9 sites with an area larger or equal to $1 \mathrm{~km}^{2}$ are considered in further analysis (Fig. 2b). The smallest area is location L3 covering $1.1 \mathrm{~km}^{2}$ of the territory, while the largest area is location L9 covering $9.1 \mathrm{~km}^{2}$. Four potential sites are located in the municipality of Pale. Three suitable sites are located in the municipality of Sokolac. The final location selection and ranking (L1 to L9) is derived using the AHP method (Table 6). According to overall priority (synthesis score value, $\mathrm{O}_{\mathrm{p}}$ ) the first ranked alternative is location L7, with an overall score 0.160 . The Second ranking alternative is location L2, with score value of 0.154 and the third ranked alternative is location L5. The last ranked alternative is the location L1.

Final results of the analysis imply the most suitable solid waste disposal site is location L7. It is located at the bordering zones of two administrative territories: Municipality of Trnovo and Municipality of Istocna Ilidza. This location covers an area of approximately $1.4 \mathrm{~km}^{2}$ and mostly belongs to the territory of Trnovo RS municipality ( $88 \%$ of the location area). The area of this site is less urbanized and less populated, with an average population density of 14 people per $\mathrm{km}^{2}$, which is lower than the national average (47 people per $\mathrm{km}^{2}$ ). Location L7 occupies rural part of the City of East Sarajevo, but not too far from highly urbanized settlements, which enables easier transport of waste

Table 5. Suitability area by municipalities of the City of East Sarajevo.

\begin{tabular}{|c|c|c|c|c|c|}
\hline Municipality & $\begin{array}{c}\text { Restricted area } \\
(\%)\end{array}$ & $\begin{array}{c}\text { Low suitability } \\
(\%)\end{array}$ & $\begin{array}{c}\text { Moderate suitability } \\
(\%)\end{array}$ & $\begin{array}{c}\text { High suitability } \\
(\%)\end{array}$ & $\sum$ \\
\hline Sokolac & 44.19 & 5.74 & 47.36 & 2.71 & 100 \\
\hline Istocno Novo Sarajevo & 61.29 & 5.38 & 31.01 & 2.32 & 100 \\
\hline Pale & 69.72 & 2.92 & 25.73 & 1.63 & 100 \\
\hline Trnovo RS & 72.34 & 4.89 & 21.53 & 1.23 & 100 \\
\hline Istocna Ilidza & 83.15 & 2.56 & 12.94 & 1.36 & 100 \\
\hline Istocni Stari Grad & 63.29 & 8.87 & 26.23 & & 1.62 \\
\hline
\end{tabular}




\begin{tabular}{|c|c|c|c|c|c|c|c|c|c|c|}
\hline & $\AA^{2}$ & $\begin{array}{l}0 \\
\vdots \\
0 \\
0\end{array}$ & $\begin{array}{l}n \\
n \\
0\end{array}$ & 吕 & $\begin{array}{l}2 \\
\ddot{0} \\
0 \\
0\end{array}$ & $\stackrel{\tilde{O}}{0}$ & 今̂. & $\stackrel{\infty}{\stackrel{0}{=}}$ & I & $\begin{array}{l}0 \\
8 \\
0\end{array}$ \\
\hline & $0^{2}$ & $\begin{array}{l}n \\
\hat{o} \\
0\end{array}$ & 苦 & $\frac{\hat{0}}{0}$ & $\begin{array}{l}8 \\
8 \\
0 \\
0\end{array}$ & $\frac{2}{3}$ & $\begin{array}{l}\tilde{O} \\
0 \\
0 \\
0\end{array}$ & $\frac{8}{8}$ & $\stackrel{n}{=}$ & ôे \\
\hline & 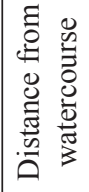 & 告 & 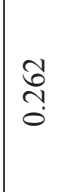 & $\begin{array}{l}0 \\
0 \\
0 \\
0\end{array}$ & $\frac{f}{0}$ & $\frac{\mathscr{O}}{0}$ & $\frac{2}{0}$ & $\overrightarrow{\tilde{\sigma}}$ & $\mid \begin{array}{l}\infty \\
0 \\
0 \\
0\end{array}$ & $\begin{array}{l}2 \\
o \\
o \\
0\end{array}$ \\
\hline & 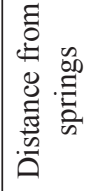 & $\overrightarrow{\tilde{\sigma}}$ & $\mid \begin{array}{c}0 \\
0 \\
0 \\
0\end{array}$ & $\begin{array}{l}\infty \\
0 \\
0 \\
0\end{array}$ & 遂 & సे & $\begin{array}{l}\vec{\infty} \\
0 \\
0\end{array}$ & กี & $\frac{8}{\circ}$ & Iิ \\
\hline & 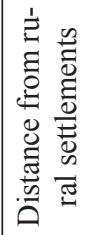 & $\begin{array}{l}\widehat{a} \\
0 \\
0\end{array}$ & 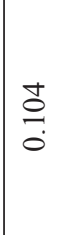 & 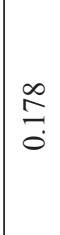 & $\begin{array}{l}\tilde{\delta} \\
0 \\
0\end{array}$ & \begin{tabular}{|l}
$\overrightarrow{0}$ \\
$\tilde{o}$
\end{tabular} & $\begin{array}{l}n \\
\delta \\
0 \\
0\end{array}$ & $\begin{array}{l}\hat{\alpha} \\
\dot{0} \\
\dot{0}\end{array}$ & $\stackrel{\infty}{\stackrel{\infty}{=}}$ & $\begin{array}{l}\infty \\
0 \\
0 \\
0\end{array}$ \\
\hline 惫 & 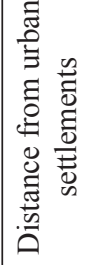 & $\begin{array}{l}0 \\
\tilde{0} \\
0 \\
0\end{array}$ & 足 & $\mid \begin{array}{l}\infty \\
0 \\
0 \\
0\end{array}$ & 吉 & ڤ̂. & $\frac{i}{n}$ & 年 & I & $\stackrel{m}{0}$ \\
\hline 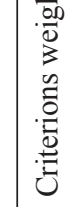 & 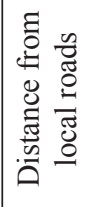 & $\stackrel{\Xi}{0}$ & $\frac{2}{2}$ & $\begin{array}{l}\text { I0 } \\
0 \\
0\end{array}$ & \begin{tabular}{|l}
0 \\
d \\
0 \\
0
\end{tabular} & 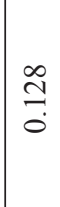 & $\begin{array}{l}0 \\
0 \\
0 \\
0\end{array}$ & \begin{tabular}{|l}
$\overrightarrow{0}$ \\
$\dot{0}$
\end{tabular} & $\vec{m}$ & \begin{tabular}{l}
0 \\
\multirow{n}{0}{} \\
0
\end{tabular} \\
\hline & 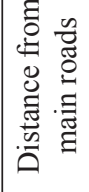 & $\begin{array}{l}\infty \\
\infty \\
0 \\
0 \\
0\end{array}$ & $\begin{array}{l}\vec{y} \\
\dot{0}\end{array}$ & $\begin{array}{l}0 \\
0 \\
0 \\
0\end{array}$ & $\hat{\tilde{o}}$ & $\stackrel{\infty}{\subseteq}$ & 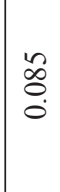 & 号 & तิ & $\begin{array}{l}\text { t. } \\
\text { ô. } \\
0\end{array}$ \\
\hline & 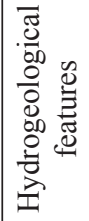 & $\stackrel{0}{I}$ & 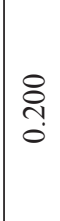 & $\overline{\tilde{n}}$ & 竎 & $\begin{array}{l}0 \\
\stackrel{0}{0} \\
0\end{array}$ & 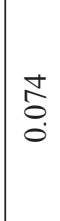 & $\mid \begin{array}{l}0 \\
0 \\
0 \\
0\end{array}$ & $\hat{\tilde{S}}$ & $\begin{array}{l}n \\
\tilde{o} \\
0\end{array}$ \\
\hline & 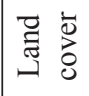 & 吕 & $\begin{array}{l}\infty \\
0 \\
0 \\
0\end{array}$ & $\begin{array}{l}0 \\
\stackrel{0}{0} \\
0 \\
0\end{array}$ & $\hat{\widehat{a}}$ & $\begin{array}{l}\tilde{\delta} \\
\tilde{0} \\
0\end{array}$ & $\begin{array}{l}0 \\
0 \\
0\end{array}$ & $\frac{a}{3}$ & $\stackrel{\tilde{n}}{0}$ & $\frac{8}{0}$ \\
\hline & $\frac{\partial}{\partial}$ & $\begin{array}{l}\stackrel{\partial}{0} \\
\dot{0} \\
\dot{0}\end{array}$ & $\hat{n}$ & $\frac{\tilde{\sigma}}{0}$ & $\begin{array}{l}\tilde{n} \\
\tilde{0}\end{array}$ & $\begin{array}{l}\tilde{O} \\
\hat{0} \\
0\end{array}$ & $\begin{array}{l}\vec{n} \\
\dot{0}\end{array}$ & ले & $\begin{array}{l}n \\
\tilde{o} \\
0\end{array}$ & $\begin{array}{l}2 \\
0 \\
0\end{array}$ \\
\hline & 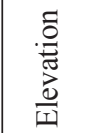 & $\begin{array}{l}\tilde{0} \\
\hat{\sigma} \\
0\end{array}$ & $\begin{array}{l}\infty \\
0 \\
0 \\
0\end{array}$ & $\begin{array}{l}\vec{\sigma} \\
0\end{array}$ & 吉 & $\stackrel{\check{n}}{\tilde{\sigma}}$ & $\begin{array}{l}\infty \\
\tilde{0} \\
0 \\
0\end{array}$ & $\begin{array}{l}\overline{\hat{\tau}} \\
\text { ch }\end{array}$ & $\hat{\tilde{O}}$ & $\begin{array}{l}0 \\
0 \\
0 \\
0\end{array}$ \\
\hline 总 & 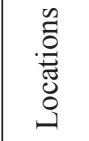 & $\exists$ & $\mathcal{I}$ & 3 & 声 & 3 & 1 & 3 & $\stackrel{\infty}{9}$ & 9 \\
\hline
\end{tabular}

in addition to lower transport costs. Other significant sites are located in the east and north-east part of the city. Location L2 is in the municipality of Sokolac (the second ranked solution) and L5 in the municipality of Pale (the third ranked solution). Since these are sparsely populated areas with the most resilient environmental features, there is less danger of pollution spreading and endangerment of people's health. Site L5, located in the Municipality of Pale, covers the area of $1.5 \mathrm{~km}^{2}$, partly occupies the territory of the settlement Strane, ( $38 \%$ of the settlement area is suitable for the solid waste disposal site). This settlement is demographically emptied out. The site L5 is connected by the main road with the urban part of the city of East Sarajevo. Quality road infrastructure can significantly facilitate waste transportation and provide easy access to site L5. Other analysed sites also have advantages by certain criterion, but to a lesser extent than sites L7, L5 and L3.

Consequently, the sensitivity analysis (Sensitivity Overall priority, $\mathrm{SO}_{\mathrm{p}}$ ), is applied to examine how robust the final judgment is. The results indicate slight difference in location (site) ranking when all criteria weights are equal to 0.100 . There is no difference in ranking by $\mathrm{Op}$ and $\mathrm{SOp}$ score value for rank positions from the first to the fourth place. The difference is observed for the site L9, which is at the fifth place according to sensitivity overall priority, while site L3 is ranked the sixth.

\section{Municipal Waste Management in Bosnia and Herzegovina}

Siting a solid waste disposal site is a very important issue in rapidly developing cities with highly accelerated process of urbanization. Suitable waste disposal sites should match these dynamic urbanization process $[64,65]$. Recent research has shown that uncontrolled waste disposal sites occupy excavations or geological depressions without additional special preparation, so waste contaminates both land and water [66]. According to Tumova [67] metallic scrap deposits can be responsible for the elevated levels of risk elements in soils in the close vicinity. Its contamination level is heterogeneous, depending on the character of the deposit and the amount and composition of the scrap material.

In Bosnia and Herzegovina only small percent of municipalities have well organized service for waste collection and disposal. Implementation of system of separate collection could decrease the amount of waste disposed to open landfills, while increasing the amount of recycled waste. All these processes could have environmental and economic benefits [68]. Some of the waste management obligations should be focused on expending the area of organized waste collection system, separating of waste collection in order to increase waste recycling and finally, to reduce the amount of biodegradable waste transferred to open landfills [69]. 
According to the legislation of the Republic of Srpska [70] municipal waste management is under supervision of local authorities which are in charge for organizing system of separation of the municipal solid waste, collection and transport system, selection of locations for recycling centres, location for recycling bins and landfills, but also covering the expenses for remediation of illegal dumpsites and unsanitary landfills. Optimal municipal waste management solutions in Bosnia and Herzegovina and the city of East Sarajevo are conditioned by harmonization of the environmental protection practices with the least financial expenses. Creating a framework for integrated solid waste management can improve cooperation between municipalities in finding the best solutions for municipal waste management and creation of regional centres for waste management. Good practices are applied in the European Union member states which are already implementing circular economy program as key policy for waste management, emphasizing necessity for transition from 'collect and dispose' waste management method to reducing waste and creating high quality streams for the processes of reuse and recovery. Countries such as Denmark, Sweden, Austria, Germany, the Netherlands and Belgium have already reached target set for 2030 of less than $10 \%$ of municipal waste landfilled [71]. Also, highly important is an application of the waste hierarchy through setting a priority order in municipal waste management with the strongest emphasis on the prevention and preparation for reuse and recycling. Less favoured choices in the recovery phase are anaerobic digestion, incineration with energy recovery, gasification and pyrolysis with energy production, due to possible negative effects of toxic gasses emission [72]. At the end of the waste treatment process is sanitary landfilling and residual waste treatment [73]. Application of these strategies in developing countries like Bosnia and Herzegovina could help in reduction of municipal waste landfilled and turn large amount of waste into valuable resources. Taking into account main strategic targets for waste management in Bosnia and Herzegovina, it is necessary to reduce the amount of waste landfilled and to increase municipal waste recycling which according to European Environmental Agency is less than $1 \%$. Good recycling practices are implemented in nearing countries, Croatia, and Hungary which have reached, $24 \%$ and $35 \%$ of recycled municipal waste [74]. Neighbouring countries such as Croatia and Serbia already made a shift from regional landfills model to model of regional waste management centres for sorting, separation and recycling. Improved waste management system should include more effective waste collection services which should cover higher percentage of businesses and households than it does nowadays, from previously covered $64 \%$ of households to $100 \%$. In the Republic of Srpska, $56 \%$ of municipal waste is packaging waste which could be recycled [75].
Even though regional separation and recycling centres are part of the strategic plans for waste management in both entities in Bosnia and Herzegovina, sanitary landfilling still remains highly necessary complementary measure due to economic deficiencies present in our country. In addition, it is highly important to take all widespread and affordable resources such as GIS with MCDA to appropriately resolve a present issue of locating municipal waste disposal sites with least possible environmental degradation while taking into account different stakeholders' interests in this process. The results of this work imply that the $2 \%$ of the area of the city of East Sarajevo can fulfil these aims. Considering nine potential sites extracted for gathered sanitary landfill of the city of East Sarajevo, site L7, followed by sites L5 and L3 are considered to be the most appropriate for location of MSWDS. The methods applied in this analysis can significantly facilitate further investigation of locational issues in waste management such as environmental suitability and site selection for regional waste separation and recycling centres as much as the location of regional landfills for energy production. The effectiveness of the results in this research can also be improved by integrating environmental and social factors with economic data which would contribute to better understanding between stakeholders and possible integration in strategic developing plans in muncipalites of the city of East Srajevo.

\section{Conclusion}

The present research investigated main factors determining environmental suitability and selecting the most suitable location for the MSWDS in the City of East Sarajevo in Bosnia and Herzegovina based on multidimensional approach. Combined method of GIS and Analytic hierarchy process with remote sensing data is applied in determination of sub-criteria and criteria values and final site selection. The study represents the analysis of environmental suitability and comparison of the identified solid waste disposal sites and final sites ranking according to the given criteria.

The results of the analysis for the investigated area of the city of East Sarajevo indicate that highly suitable area for the location of solid waste disposal site covers only $2 \%$ of city territory or $30.67 \mathrm{~km}^{2}$. Nine locations with an area larger than $1 \mathrm{~km}^{2}$ were extracted within a high suitability class. Final ranking performed through sites comparison in AHP shows the most suitable site is L7 in the municipality of Trnovo RS. In just two municipalities, Pale and Sokolac, 7 potential sites are located. The highest percentage of the area suitable for location of MSWDS is in the Sokolac municipality, covering the total area of $18 \mathrm{~km}^{2}$, or $2.7 \%$ of the territory, while the smallest area of high suitability category is in the municipality of Istocna Ilidza. 
The problem of sustainable waste management came into focus by numerous studies and scientific research. The intensified production and high availability of various consumer goods affect constant growth of waste production. The aim of this work was to present integrated methodology of multi-criteria analysis and geographic information system and emphasize the opportunities this method offers in the process of decision-making in environmental studies. Multi-criteria methods provide a multi-dimensional approach to problems by considering different aspects of the problem and taking into account different stakeholders in the decision-making process. Such methodological properties of multi-criteria analysis enable their successful application in environmental and spatial sciences, especially from the perspective of environmental planning and environmental management. The relatively accessible and practical GIS tools make it possible to conduct analysis of different spatial scope with a high degree of reliability. Geographical information systems (GIS) and multicriteria decision making (MCDM), applied through pairwise comparison matrices in analytic hierarchy process (AHP) can be very useful tool in the waste management, especially with regard to comprehensive decision-making process such as the environmental suitability analysis and selection of the most suitable location for MSWDS

Implementation of these methodologies and obtained results are in accordance with previously defined strategies of waste management. Just coordinated work and integrated activities of experts, researchers, government and municipal officials as much as citizens and other stakeholders can significantly improve municipal waste management in Bosnia and Herzegovina. The strongest strategic focus is on the enlargement of municipal waste collection system, opening regional centers for recycling and reuse processes in coordination with environmentally and financially feasible solutions of locating gathered sanitary landfills for municipal solid waste disposal. This could provide financial payback and the opportunity to partially refund money invested in maintenance of waste management systems while keeping people and the environment safe. This research can be applied by city's official agencies for spatial planning and environmental management and protection as it obtains useful informational bases, necessary for creation of environmental protection strategies, city development strategy and information for spatial plan of the City of East Sarajevo. Moreover, the results of this study can be included in local municipal solid waste management plans of the municipalities of Trnovo RS, Pale, Istocna Ilidza, Istocno Novo Sarajevo, Istocni Stari Grad and Sokolac. The applied methodology and presented results can be a guiding model for similar analysis in other cities and municipalities in Bosnia and Herzegovina which are dealing with locational problems in complicated environmental and waste management issues.

\section{Acknowledgment}

The authors are grateful to the administration of the City of East Sarajevo for providing necessary data for this research.

\section{Conflict of Interest}

The authors declare no conflict of interest.

\section{References}

1. KAZA S., YAO L., BHADA-TATA P., VAN WOERDEN F. What a waste 2.0: a global snapshot of solid waste management to 2050. Urban Development. World Bank Publications: Washington, DC, USA, 47, 2018. Available online: https://openknowledge.worldbank.org/ (accessed on 21.08.2019.)

2. SINGH R.P., TYAGI V.V., ALLEN T., IBRAHIM M.H., KOTHARI R. An overview for exploring the possibilities of energy generation from municipal solid waste (MSW) in Indian scenario. Renewable and Sustainable Energy Reviews, 15 (9), 4797, 2011.

3. TOZLU A., ÖZAHI E., ABUŞOĞLU A. Waste to energy technologies for municipal solid waste management in Gaziantep. Renewable and Sustainable Energy Reviews, 54, 809, 2016.

4. GRONBA-CHYŁA A., GENEROWICZ A., KRAMEK A. Using Selected Types of Waste to Produce New Light Ceramic Material. Polish Journal of Environmental Studies, 30 (3), 2073, 2021.

5. VALJAREVIĆ A., VALJAREVIĆ D., FILIPOVIĆ D., DRAGOJLOVIĆ J., MILOSAVLJEVIĆ S., MILANOVIĆ M. One Small Municipality and Future of Renewable Energy Strategy. Polish Journal of Environmental Studies, 30 (1), 1, 2021.

6. KUMAR A., SAMADDER S.R. A review on technological options of waste to energy for effective management of municipal solid waste. Waste Management, 69, 407, 2017.

7. BALAT M. Biomass Energy and Biochemical Conversion Processing for Fuels and Chemicals. Energy Sources, Part A., 28 (6), 517, 2006.

8. LARNEY F.J., SULLIVAN D.M., BUCKLEY K.E., EGHBALL B. The role of composting in recycling manure nutrients. Canadian Journal of Soil Science, 86 (4), 597, 2006.

9. READ A.D., HUDGINS M., HARPER S., PHILLIPS P., MORRIS J. The successful demonstration of aerobic landfilling: The potential for a more sustainable solid waste management approach? Resources, Conservation and Recycling, 32 (2), 115, 2001.

10. WARITH M.A. Solid waste management: new trends in landfill design. Emirates Journal for Engineering Research, 8 (1), 61, 2003.

11. OAKLEY S.M., JIMENEZ R. Sustainable sanitary landfills for neglected small cities in developing countries: The semi-mechanized trench method from Villanueva, Honduras. Waste Management, 32 (12), 2535, 2012.

12. MADON I., DREV D., LIKAR J. Long-term risk assessments comparing environmental performance of different types of sanitary landfills. Waste Management, 96, 96, 2019. 
13. VUJIĆ G., GONZALEZ-ROOF A., STANISAVLJEVIĆ N., RAGOSSNIG A.M. Municipal solid waste development phases: Evidence from EU27. Waste Management and Research, 33 (12), 1112, 2015.

14. MUNAWAR E., YUNARDI Y., LEDERER J., FELLNER $\mathrm{J}$. The development of landfill operation and management in Indonesia. Journal of Material Cycles and Waste Management, 20 (2), 1128, 2018

15. STANIC-MARUNA I. What you sow today, you will reap tomorrow - the future of landfilling in Croatia. From Sanitary to Sustainable Landfilling: Why, How and When?. First International Conference on Final Sinks, 23-25 September 2010, Fellner J., Ed., Vienna, Austria, 78, 2010.

16. LUKIĆ TANOVIĆ M., GOLIJANIN J., ŠUŠNJAR S. Impact of population on the karst of East Sarajevo (Bosnia and Herzegovina). Journal of the Geographical Institute Jovan Cvijic SASA, 69 (2), 95, 2019.

17. TELBISZ T., IMECS Z., MARI L., BOTTLIK Z. Changing Human-Environment Interactions in Medium Mountains: the Apuseni Mts (Romania) as a Case Study. Journal of Mountain Science, 13 (9), 1675, 2016.

18. MAMAT A., HALIK U., ROUZI A. Spatial Evaluation of Environmental Suitability for Human Settlements Based On GIS: A Case Study in Kaidu River Basin, Northwest China. Fresenius Environmental Bulletin, 27, 132, 2018.

19. WU W., ZHANG X., YANG Z., QIN W., WANG F., WANG C. Ecotourism Suitability and Zoning from the Tourist Perspective: a Nature Reserve Case Study. Polish Journal of Environmental Studies, 24 (6), 2683, 2015.

20. KONTOS T.D., KOMILIS D.P., HALVADAKIS C.P. Siting MSW landfills with a spatial multiple criteria analysis methodology. Waste management, 25 (8), 818, 2005.

21. HANDAKAS E.J., SANGIANNIS D.A. Solid waste management: a systems approach. Fresenius Environmental Bulletin, 21 (11), 3330, 2012.

22. BERISA G., BIRHANU Y. Municipal Solid Waste Disposal Site Selection of Jigjiga town using GIS and remote sensing techniques, Ethiopia. International Journal of Scientific and Research Publications, 5 (4), 1, 2015.

23. SHAH S.A.A., KHAN Z., NAWAZ S. Identification of Suitable Sites for Solid Waste Disposal using GIS Multicriteria Analysis in Peshawar, Pakistan: Identification of Suitable Sites for Solid Waste Disposal. Proceedings of the Pakistan Academy of Sciences: B. Life and Environmental Sciences, 53 (4), 309, 2016.

24. BILGILIOĞLU S.S., BILGILIOĞLU B. Selection of suitable site for municipal solid waste disposal sites for the Aksaray (Turkey) using AHP and GIS Methods. Journal of Scientific and Engineering Research, 4 (11), 36, 2017.

25. DIMOPOULOU E., TOLIDIS K., ORFANOUDAKIS Y., ADAM K. Spatial multi-criteria decision analysis for site selection of sustainable stone waste disposal. Fresenius Environmental Bulletin, 22 (7), 2022, 2013.

26. ASIF K., CHAUDHRY M.N., ASHRAF U., ALI I., ALI M. A GIS-Based Multi-Criteria Evaluation of Landfill Site Selection in Lahore, Pakistan. Polish Journal of Environmental Studies, 29 (2), 1511, 2020.

27. GOULART COELHO L.M., LANGE L.C., COELHO H.M. Multi-criteria decision making to support waste management: A critical review of current practices and methods. Waste Management and Research, 35 (1), 3, 2017.

28. INSTITUTE OF STATISTICS OF THE REPUBLIC OF SRPSKA. Census of population, households and dwellings in Republic of Srpska 2013. Banja Luka, Bosnia and Herzegovina, 2017.
29. MUNICIPALITY OF ISTOCNA ILIDZA. State of the environment report - LEAP 2012-2018. Istocna Ilidza, Bosnia and Herzegovina, 2011 [In Serbian].

30. MUNICIPALITY OF ISTOCNO NOVO SARAJEVO. State of the environment report - LEAP 2012-2016. Istocno Novo Sarajevo, Bosnia and Herzegovina, 2011 [In Serbian].

31. MUNICIPALITY OF PALE. State of the environment report - LEAP 2012-2018. Pale, Bosnia and Herzegovina, 2011 [In Serbian].

32. MUNICIPALITY OF SOKOLAC. State of the environment report - LEAP. Sokolac, Bosnia and Herzegovina, 2011 [In Serbian].

33. MINISTRY OF ECONOMY, TRADE, AND INDUSTRY (METI) OF JAPAN AND NASA. ASTER GLOBAL DIGITAL ELEVATION MODEL, version 2, ASTGTM2 N43E018, ASTGTM2_N43E019, ASTGTM2_N44E018 \& ASTGTM2_N44E019. Available online: https:// earthexplorer.usgs.gov/, (accessed on 06.02.2019.)

34. MILITARY GEOGRAPHICAL INSTITUTE. Basic topographical map 1:100000, sheets Gorazde, Sarajevo, Kladanj, Visegrad. Belgrade, SFRY, 1971 [In Serbian].

35. GOOGLE HYBRID BASEMAP (obtained through QuickMapServices QGIS plugin), Map data, 2015.

36. QGIS DEVELOPMENT TEAM. QGIS GEOGRAPHIC INFORMATION SYSTEM, Version 3.4. Open Source Geospatial Foundation Project. 2018. Available online: https://qgis.org/en/site/ (accessed on 28.11.2018.)

37. INSTITUTE FOR GEOLOGICAL RESEARCH OF THE REPUBLIC OF SRPSKA GEOZAVOD AND THE FEDERAL INSTITUTE FOR GEOLOGY. Fragment of basic hydrogeological map of SFRY 1:500.000. Zvornik, Sarajevo, Bosnia and Herzegovina, 1980 [ In Serbian].

38. LANDSAT 8 Image courtesy of the U.S. Geological Survey. The Operational Land Imager and the Thermal Infrared Sensor, LC81870292017223LGN00, LC81870302017223LGN00. date acquired: 11.08. 2017. Available online: https://earthexplorer.usgs.gov/ (accessed on 10.04.2020.)

39. AHMAD A., QUEGAN S. Analysis of maximum likelihood classification on multispectral data. Applied Mathematical Sciences, 6 (129), 6425, 2012.

40. MALCZEWSKI J. GIS-based multicriteria decision analysis: a survey of the literature. International journal of geographical information science, 20 (7), 703, 2006.

41. LU D., WENG Q. A survey of image classification methods and techniques for improving classification performance. International journal of Remote sensing, $\mathbf{2 8}$ (5), 823, 2007.

42. BOUCHER A., KYRIAKIDIS P.C. Super-resolution land cover mapping with indicator geostatistics. Remote Sensing of Environment, 104 (3), 264, 2006.

43. VALJAREVIĆ A., DJEKIĆ T., STEVANOVIĆ V., IVANOVIĆ R., JANDZIKOVIĆ B. GIS numerical and remote sensing analyses of forest changes in the Toplica region for the period of 1953-2013. Applied Geography, 92, 131, 2018.

44. VALJAREVIĆ A., FILIPOVIĆ D., VALJAREVIĆ D., MILANOVIĆ M., MILOŠEVIĆ S., ŽIVIĆ N., LUKIĆ T. GIS and remote sensing techniques for the estimation of dew volume in the Republic of Serbia. Meteorological Applications, 27 (3), e1930, 2020.

45. SUN J., YANG J., ZHANG C., YUN W., QU J. Automatic remotely sensed image classification in a grid environment based on the maximum likelihood method. Mathematical and Computer Modelling, 58 (3-4), 573, 2013. 
46. RICHARDS J.A. Supervised Classification Techniques. In Remote Sensing Digital Image Analysis, Fifth Ed.; Springer: Berlin, Heidelberg, Germany, 247, 2013.

47. MALCZEWSKI J. GIS-based land-use suitability analysis: a critical overview. Progress in Planning, 62 (1), 3, 2004.

48. ASIF K., CHAUDHRY M.N., ASHRAF U., ALI I., ALI M. A GIS-Based multi-criteria evaluation of landfill site selection in Lahore, Pakistan. Polish Journal of Environmental Studies, 29 (2), 1511, 2020.

49. ALI S.A., AHMAD A. Suitability analysis for municipal landfill site selection using fuzzy analytic hierarchy process and geospatial technique. Environmental Earth Sciences, 79, 1, 2020.

50. TORABI-KAVEH M., BABAZADEH R., MOHAMMADI S.D., ZARESEFAT M. Landfill site selection using combination of GIS and fuzzy AHP, a case study: Iranshahr, Iran. Waste Management and Research, 34 (5), 438, 2016.

51. ABDULHASAN M.J., HANAFIAH M.M., SATCHET M.S., ABDULAALI H.S., TORIMAN M.E., AL-RAAD A.A. Combining GIS, fuzzy logic and AHP models for solid waste disposal site selection in Nasiriyah, Iraq. Applied Ecology and Environmental Research, 17 (3), 6701, 2019.

52. KUMAR V., YADAV K., RAJAMANI V. Selection of Suitable Site for Solid Waste Management in Part of Lucknow City, Uttar Pradesh using Remote Sensing, GIS and AHP Method. International Journal of Engineering Research, 3 (3), 1461, 2014.

53. ERROUHI A.A., BAHI L., OUADIF L., AKHSSAS A., BOUROUMINE Y., BAHI A. Evaluation of landfill site choice using AHP and GIS case study: Oum Azza, Morocco. In MATEC Web of Conferences. EDP Sciences, Volume 149, 02047, 2018.

54. ZAKERIAN S., MOKHTARI M., ALMODARESI S.A.A. Evaluation of a Landfill Site Using AHP and TOPSIS Models: A Case Study of Ardakan Landfill, Iran. Avicenna Journal of Environmental Health Engineering, 2 (1), 754, 2017.

55. SAATY T.L. Decision making with the analytic hierarchy process. International journal of services sciences, 1 (1), 83, 2008

56. SAATY R.W. The analytic hierarchy process - what it is and how it is used. Mathematical Modelling, 9 (3-5), 161, 1987.

57. SAATY T.L. How to Make a Decision: The Analytic Hierarchy Process. European journal of operational research, 48 (1), 9, 1990.

58. TRIANTAPHYLLOU E., MANN S.H. Using the analytic hierarchy process for decision making in engineering applications: some challenges. International Journal of Industrial Engineering: Applications and Practice, 2 (1), 35, 1995.

59. MU E., PEREYRA-ROJAS M. Understanding the analytic hierarchy process. In Practical decision making, Springer International Publishing: Cham, Switzerland, 7, 2017.

60. EASTMAN J.R. Multi-criteria evaluation and GIS. Geographical information systems, 1 (1), 493, 1999.

61. EASTMAN J.R. Raster procedure for urban multicriterial multi objective decisions photogram metric engineering \& remote sensing, American Society for Photogrammetry and Remote Sensing, 61, 539, 1995.

62. MALCZEWSKI J. On the use of weighted linear combination method in GIS: common and best practice approaches. Transactions in GIS, 4 (1), 5, 2000.
63. DROBNE S., LISEC A. Multi-attribute Decision Analysis in GIS: weighted linear combination and ordered weighted averaging. Informatica, 33 (4), 459, 2009.

64. WANG G., QIN L., LI G., CHEN L. Landfill site selection using spatial information technologies and AHP: a case study in Beijing, China. Journal of environmental management, 90 (8), 2414, 2009.

65. BUZJAK N., VUK D., JAKOVČIĆ M. The Issue of Landfill Location: Example of the Tarno Site (Zagreb County, Croatia). Sociologija i prostor: časopis za istraživanje prostornoga i sociokulturnog razvoja, 53 (2 (202)), 117, 2015.

66. CALÒ F., PARISE M. Waste management and problems of groundwater pollution in karst environments in the context of a post-conflict scenario: The case of Mostar (Bosnia Herzegovina). Habitat International, 33 (1), 63, 2009.

67. TŮMOVÁ K., SZÁKOVÁ J., NAJMANOVÁ J., TLUSTOŠ P. Scrap Metal Deposits as Potential Sources of Enhanced Risk in Soil and Vegetation. Polish Journal of Environmental Studies, 29 (1), 841, 2019.

68. VACCARI M., DI BELLA V., VITALI F., COLLIVIGNARELLI C. From mixed to separate collection of solid waste: Benefits for the town of Zavidovici (Bosnia and Herzegovina). Waste Management, 33 (2), 277, 2013.

69. ULFIK A., NOWAK S. Determinants of Municipal Waste Management in Sustainable Development of Regions in Poland. Polish Journal of Environmental Studies, 23 (3), 1039, 2014

70. THE LOW OF WASTE MANAGEMENT OF RS. Službeni glasnik RS, 36/2009, 88/2010, 14/2016 and 95/2018 [In Serbian].

71. LEE P., SIMS E., BERTHAM O., SYMINGTON H., BELL N., PFALTZGRAFF L., SJÖGREN P., WILTS C.H., O'BRIEN M. Towards a circular economy: waste management in the EU, study. 2017. Available online: https://epub.wupperinst.org/frontdoor/deliver/index/ docId/6863/file/6863_Circular_Economy.pdf (accessed on 09.03.2021.)

72. MARCETA U., VUJIC B., SRDJEVIC Z., MIHAJLOVIC V., RADOSAV D. Multi-Criteria Decision-Making Model to Support Landfill Prioritization: Methane Risk Assessment. Polish Journal of Environmental Studies, 30 (2), 1297, 2021.

73. HOGG D., VERGUNST T., ELLIOT T., BREUSEGEM W., NICOLOPOULOS K., KOTSANI C., KRIVOKAPIC M., MILJANIC O., MIKALACKI J., MADZAREVIC I. A comprehensive assessment of the current waste management situation in South East Europe and future perspectives for the sector including options for regional cooperation recycling of electric and electronic waste. Final Report. Eunomia. 2017. Available online: https:// op.europa.eu/en/publication-detail/-/publication/1325fc9d1831-11e7-808e-01aa75ed71al (accessed on 14.03.2021.)

74. EUROPEAN ENVIRONMENTAL AGENCY: STATISTICAL OFFICE OF THE EUROPEAN UNION (EUROSTAT). Waste recycling. Prod-ID: IND-378-en also known as CSI 052, WST 005. Published 22 Nov 2019. Available online: https://www.eea.europa.eu/data-andmaps/indicators/waste-recycling-1/assessment-1 (accessed on 10.03.2021.)

75. GOVERNMENT OF THE REPUBLIC OF SRPSKA. Waste management Strategy of Republic of Srpska for 2017-2026, Banja Luka, Bosnia and Herzegovina, 2017 [In Serbian] Available online: https://e-vijecenarodars.net/wpcontent/uploads/2017/07/Prijedlog-strategije-upravljanjaotpadom-2017-2026.pdf (accessed on 14.03.2021.) 